\title{
Acute toxic effects of hydrogen peroxide, used for salmon lice treatment, on the survival of polychaetes Capitella sp. and Ophryotrocha spp.
}

\author{
Jinghui Fang ${ }^{1,2,3}$, Ole B. Samuelsen ${ }^{3, *}$, Øivind Strand ${ }^{3}$, Henrice Jansen ${ }^{3,4}$ \\ ${ }^{1}$ Key Laboratory for Sustainable Utilization of Marine Fisheries Resources, Ministry of Agriculture, \\ Yellow Sea Fisheries Research Institute, Qingdao 266071, PR China \\ ${ }^{2}$ Laboratory for Marine Fisheries Science and Food Production Processes, \\ Qingdao National Laboratory for Marine Science and Technology, Qingdao 266237, PR China \\ ${ }^{3}$ Institute of Marine Research, PO Box 1870 Nordnes, Bergen 5817, Norway \\ ${ }^{4}$ Institute for Marine Resources and Ecosystem Studies, Yerseke $4400 \mathrm{AB}$, The Netherlands
}

\begin{abstract}
The amount of hydrogen peroxide $\left(\mathrm{H}_{2} \mathrm{O}_{2}\right)$ used in the treatment of salmon lice in Norwegian salmon farming increased from 308 tons in 2009 to 43246 tons in 2015. For 2016 and 2017, however, the consumption was reduced to 26597 and 9277 tons, respectively. The use of this compound may have negative impacts on benthic fauna underneath the fish farms and, in particular, on polychaetes, which can be found in large numbers at the bottom under fish farms where they play a key role in the turnover of organic waste from the farm. The tolerance of Capitella sp. and Ophryotrocha spp. to a $1 \mathrm{~h}$ exposure to $\mathrm{H}_{2} \mathrm{O}_{2}\left(0,100,200,400,800,1200\right.$ and $\left.1800 \mathrm{mg} \mathrm{l}^{-1}\right)$ was evaluated. The recommended dose for treatment of the salmon is $1800 \mathrm{mg} \mathrm{l}^{-1}$. Following exposures, the polychaetes were reintroduced into clean sea water. Both polychaete species experienced high cumulative mortality during a $72 \mathrm{~h}$ post-exposure period. The mortality showed to be dose dependent, with the highest dose giving the highest mortality. The $50 \%$ lethal concentration $\left(\mathrm{LC}_{50}\right)$ of Capitella sp. was significantly higher than the $\mathrm{LC}_{50}$ of Ophryotrocha spp. at the same exposure time $(\mathrm{p}<0.05)$. The $50 \%$ lethal time of Capitella sp. was significantly longer than that of Ophryotrocha spp. at the same concentration $(\mathrm{p}<0.05)$. The results show that $1 \mathrm{~h}$ exposures to $\mathrm{H}_{2} \mathrm{O}_{2}$ at all the tested concentrations had irreversible negative effects on both polychaete species.
\end{abstract}

KEY WORDS: Hydrogen peroxide $\cdot$ Polychaete $\cdot$ Acute toxicity $\cdot$ Mortality $\cdot \mathrm{LC}_{50}$

\section{INTRODUCTION}

The ectoparasite salmon louse Lepeophtheirus salmonis (Krøyer 1837) is a major problem for the cage farming of Atlantic salmon Salmo salar in Norway. A number of compounds are therefore available to combat the parasite, including chitin synthesis inhibitors, acetylcholinesterase inhibitors, pyrethroids, avermectins and the antiseptic hydrogen peroxide $\left(\mathrm{H}_{2} \mathrm{O}_{2}\right)$. Because of the reduced sensitivity of salmon lice to

*Corresponding author: oles@IMR.no pyrethroids and emamectin and the emergence of amoebic gill disease in Norwegian salmon farming, the use of $\mathrm{H}_{2} \mathrm{O}_{2}$ has steadily increased since 2009, reaching a total of 43246 tons in 2015 (Adams et al. 2012, Grøntvedt et al. 2015). In the last 2 yr, however, the consumption has been reduced to 26597 tons in 2016 and further to 9277 tons in 2017 (www.fhi.no/). $\mathrm{H}_{2} \mathrm{O}_{2}$ is used as bath treatment, and prior to administration, the water volume in the cage is temporarily reduced and the cage surrounded by a tarpaulin. The

(C) The authors 2018. Open Access under Creative Commons by Attribution Licence. Use, distribution and reproduction are unrestricted. Authors and original publication must be credited. 
$\mathrm{H}_{2} \mathrm{O}_{2}$ is added to the cage to a final bath concentration of 1500 to $1800 \mathrm{mg} \mathrm{l}^{-1}$ depending on temperature, and the exposure time is 20 to $30 \mathrm{~min}$. Following treatment, the tarpaulin is removed and the released $\mathrm{H}_{2} \mathrm{O}_{2}$ may disperse both vertically and horizontally. Since a bath solution of $\mathrm{H}_{2} \mathrm{O}_{2}$ is slightly heavier than the surrounding sea water, modeling has shown that the plume may sink after release if the water column is homogeneous (Refseth et al. 2016). This was confirmed by Fagereng (2016), who, in a field investigation, found up to $724 \mathrm{mg} \mathrm{l}^{-1}$ of $\mathrm{H}_{2} \mathrm{O}_{2}$ at a depth of $60 \mathrm{~m}$ and detectable concentrations even at $130 \mathrm{~m}$. Coupled with a predicted no-effect concentration of $0.01 \mathrm{mg} \mathrm{l}^{-1}$ determined for $\mathrm{H}_{2} \mathrm{O}_{2}$ in water (Institute for Health and Consumer Protection in Finland 2003), the results of Fagereng (2016) suggest that the use of $\mathrm{H}_{2} \mathrm{O}_{2}$ in salmon farming may be harmful to nontarget organisms located near salmon farms and, given the right conditions, benthic organisms like polychaetes may also be exposed.

$\mathrm{H}_{2} \mathrm{O}_{2}$ has long been regarded as an environmentally friendly salmon lice agent because it readily dissociates to water and oxygen. However, Fagereng (2016) calculated degradation half-lives of 28 and $3.5 \mathrm{~d}$ of $\mathrm{H}_{2} \mathrm{O}_{2}$ in seawater at temperatures of 8.7 and $12^{\circ} \mathrm{C}$, respectively. Furthermore, it has been shown that low concentrations $\left(<0.170 \mathrm{mg} \mathrm{l}^{-1}\right)$ of $\mathrm{H}_{2} \mathrm{O}_{2}$ affect the physiology of aquatic animals, such as antioxidant enzyme activities in the polychaetes Arenicola marina and Nereis (Hediste) diversicolor (AbeleOeschger et al. 1994, Buchner et al. 1996). Effects on oxygen consumption, catalase and glutathione peroxidase activity were further seen in the polychaete Laeonereis acuta when exposed to concentrations of 0.34 and $1.7 \mathrm{mg} \mathrm{l}^{-1}$ for up to $10 \mathrm{~d}$ (da Rosa et al. 2008). The acute effects of high concentrations of $\mathrm{H}_{2} \mathrm{O}_{2}$ on aquatic invertebrates are largely unknown, but Fagereng (2016) showed that $1 \mathrm{~h}$ exposure of pink shrimps Pandalus montagui to $170 \mathrm{mg} \mathrm{l}^{-1}$ led to reduced flight response even after a $24 \mathrm{~h}$ recovery period. A $1 \mathrm{~h}$ exposure of copepods Calanus sp. gave a $50 \%$ lethal concentration $\left(\mathrm{LC}_{50}\right)$ of less than $5 \%$ of the recommended dose of $1700 \mathrm{mg} \mathrm{l}^{-1}$ (Escobar-Lux 2016). On the other hand, a $1 \mathrm{~h}$ exposure gave an $\mathrm{LC}_{50}$ higher than $1700 \mathrm{mg} \mathrm{l}^{-1}$ for sand shrimp Crangon septemspinosa, rock pool shrimp Palaemon elegans, chameleon shrimp Praunus flexuosus and adult American lobster Homarus americanus (Burridge et al. 2014, Brokke 2015). Hence, major differences in sensitivity between species are seen. Therefore, there is a need for more knowledge about the effect of $\mathrm{H}_{2} \mathrm{O}_{2}$ exposure on non-target organisms, especially for benthic species.
Polychaetes are naturally abundant in benthic habitats under fish farms and in other types of anthropogenically modified estuaries (Kutti et al. 2007, Dafforn et al. 2013, Bannister et al. 2014). Opportunistic polychaetes that are adapted to nutrient-rich habitats and commonly found underneath fish farms located over hard bottom in Norway include Vigtorniella ardabilia and Ophryotrocha spp. (Paxton \& Davey 2010, R. Bannister pers. comm.) and over soft-sediment areas, Capitella sp. (Kutti et al. 2007, Dean 2008). The polychaetes are important in environmental recovery by consuming and transforming the organic materials deposited from the fish farm (Dean 2008). Because these species live near the fish farms, they may be exposed to agents originating from activities at the farm, including salmon lice treatment. The objective of this study was therefore to find the limit of tolerance of Capitella sp. and Ophryotrocha spp. to short time exposure to $\mathrm{H}_{2} \mathrm{O}_{2}$. This will contribute to the evaluation of the effects of sea lice drugs on the natural environment surrounding fish cages.

\section{MATERIALS AND METHODS}

\section{Animal collection and acclimatization}

Capitella sp. were collected by grab sampling $\left(250 \mathrm{~cm}^{2}\right)$ underneath a fish farm located at Austevoll, Norway. Ophryotrocha spp. were collected at a fish farm in Hardangerfjord, Norway, using artificial plastic grass mounted in an iron frame of $1.2 \times 1.2 \times$ $0.1 \mathrm{~m}$ and deployed underneath a fish cage for $2 \mathrm{wk}$. The collected polychaetes under the fish farms were representative species. At both fish farms, alternative methods (fresh water, increased water temperature) had recently been used for delousing purposes. Directly after sampling, polychaetes were placed in boxes containing sea water collected from about $150 \mathrm{~m}$ depth. The boxes, supplied with air, were transported to the laboratory at Austevoll Research Station (Institute of Marine Research, Norway). Capitella sp. specimens were placed in four $100 \mathrm{l}$ tanks, with $1 \mathrm{~kg}$ of glass beads (6 mm diameter) in each tank mimicking artificial benthic substrate. The Ophryotrocha spp. were placed in 1001 tanks, each supplied with 5 stones of about $300 \mathrm{~g}$ serving as substrate. The stones facilitated aggregation of Ophryotrocha spp. and provided a rough substrate to attach mucus strings, mimicking a hard-bottom substrate. Tanks were supplied with a seawater flow of 1150 to $1500 \mathrm{ml} \mathrm{min}^{-1}$ from $150 \mathrm{~m}$ depth holding 
a temperature of 8 to $9^{\circ} \mathrm{C}$. The polychaetes were acclimatized for $5 \mathrm{~d}$ and fed ground salmon pellets produced by Skretting once a day. The tanks were kept in darkness during the acclimation period, except during feeding.

\section{Experimental design}

Polychaetes were exposed to 6 nominal concentrations of $\mathrm{H}_{2} \mathrm{O}_{2}(100,200,400,800,1200,1800 \mathrm{mg}$ $\mathrm{l}^{-1}$ ) for $1 \mathrm{~h}$, where the highest concentration is equal to the recommended dose used for treatment. Concentrations were prepared by diluting the stock formulation (Nemona 49, 5\%, Akzo Nobel) with sea water to the desired concentration for each treatment. The polychaetes (>50 individuals, estimated from pre-calculated volume per numbers) were transferred to $2 \mathrm{l}$ beakers containing the decided concentration of $\mathrm{H}_{2} \mathrm{O}_{2}$. Beakers without $\mathrm{H}_{2} \mathrm{O}_{2}$ served as controls. Three replicate groups were used for each concentration, including control groups. Following exposure $(1 \mathrm{~h})$, the $\mathrm{H}_{2} \mathrm{O}_{2}$ solution in the beaker was replaced with clean water and a continuous flow (150-180 $\mathrm{ml} \mathrm{min}^{-1}$ ) of sea water established. The number of dead animals was recorded at $1,6,12,24,48$ and $72 \mathrm{~h}$ from the start of $\mathrm{H}_{2} \mathrm{O}_{2}$ exposure; the number of remaining survivors was also counted at $72 \mathrm{~h}$. Beakers were kept in the dark during the experimental period.

\section{Statistical analysis}

The $50 \%$ lethal time $\left(\mathrm{LT}_{50}\right)$ is the time where $50 \%$ of the organisms have died after exposure to a toxic substance or stressful condition. The $\mathrm{LC}_{50}$ refers to the concentration for half the population to die from a treatment or exposure. The $\mathrm{LC}_{50}$ and $\mathrm{LT}_{50}$ values were calculated by the Bliss Probit Method (Sprague 1969). Data were analyzed using the SPSS for Windows (Version 13.0) statistical package. The calculated $\mathrm{LC}_{50}$ and $\mathrm{LT}_{50}$ values are presented as mean \pm $\mathrm{SD}$, unless stated otherwise. The differences in mortalities for each treatment and time intervals were assessed with 1-way ANOVA followed by Duncan's multiple range tests for post hoc pairwise comparisons. A dependent $t$-test was applied to detect any differences between $\mathrm{LT}_{50}$ and $\mathrm{LC}_{50}$ for the 2 species. Curve estimation was used to analyze the relationship between $\mathrm{LC}_{50}$ and time and between $\mathrm{LT}_{50}$ and concentrations. Differences were statistically significant if $\mathrm{p}<0.05$.

\section{RESULTS}

\section{Mortality}

For Capitella sp., no mortality was seen in the control groups. In the $\mathrm{H}_{2} \mathrm{O}_{2}$-exposed groups, the acute mortality after $1 \mathrm{~h}$ exposure was dose dependent, with the 2 highest doses giving a mortality of $>60 \%$. A delay in mortality, on the other hand, was seen for the 100, 200 and $400 \mathrm{mg} \mathrm{l}^{-1}$ doses (Fig. 1a). The cumulative mortality increased gradually throughout the experimental period of $72 \mathrm{~h}$, reaching over $90 \%$ for all doses except for $100 \mathrm{mg} \mathrm{l}^{-1}$, which reached $76 \%$ (Fig. 1a).

The sensitivity of Ophryotrocha spp. to $\mathrm{H}_{2} \mathrm{O}_{2}$ was significantly higher than that of Capitella sp. A $1 \mathrm{~h}$ exposure resulted in acute mortality for all doses, reaching $100 \%$ for the 1200 and $1800 \mathrm{mg} \mathrm{l}^{-1}$ doses and $20 \%$ for the $100 \mathrm{mg} \mathrm{l}^{-1}$ dose (Fig. 1b). After $72 \mathrm{~h}$, the cumulative mortalities were nearly $100 \%$ for all doses (Fig. 1b). Some mortality was registered in the control beaker but was less than $10 \%$ after $72 \mathrm{~h}$.

\section{$\mathrm{LC}_{50}$ and $\mathrm{LT}_{50}$}

A significant relation was found between $\mathrm{LC}_{50}$ and exposure time for both Capitella sp. and Ophryotrocha spp. ( $\mathrm{p}<0.05$, Fig. 2). The curve estimation analysis for the $\mathrm{LC}_{50}$ of Capitella sp. showed a higher

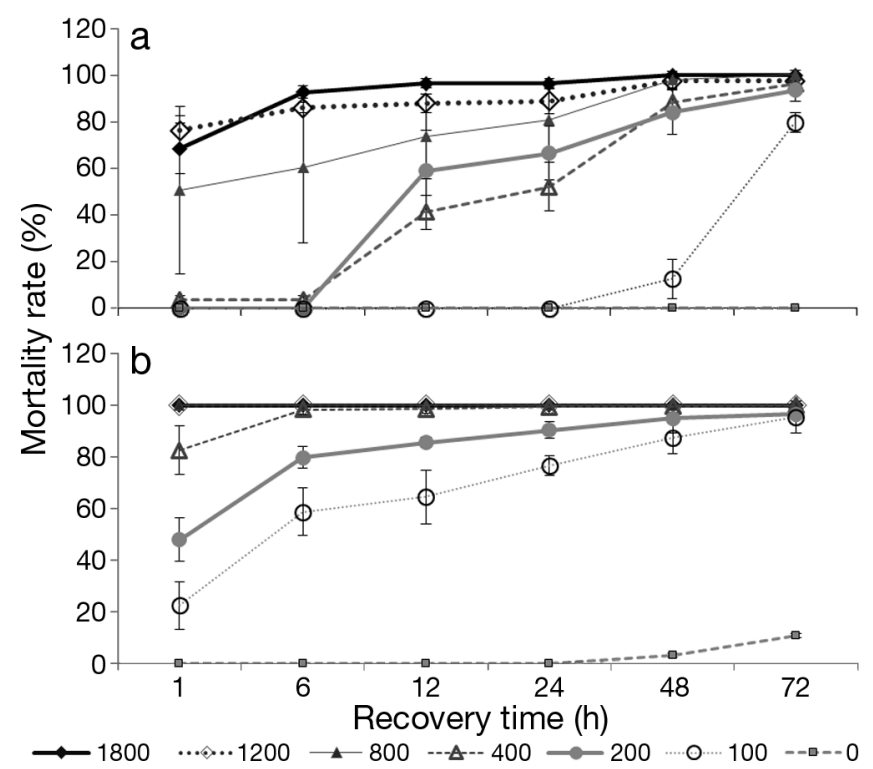

Fig. 1. Average mortality of (a) Capitella sp. and (b) Ophryotrocha spp. at exposure concentrations $(0,100,200,400,800$, 1200, $1800 \mathrm{mg} \mathrm{l}^{-1}, \mathrm{n}=3$ ) of hydrogen peroxide. Error bars represent $1 \mathrm{SD}$ 


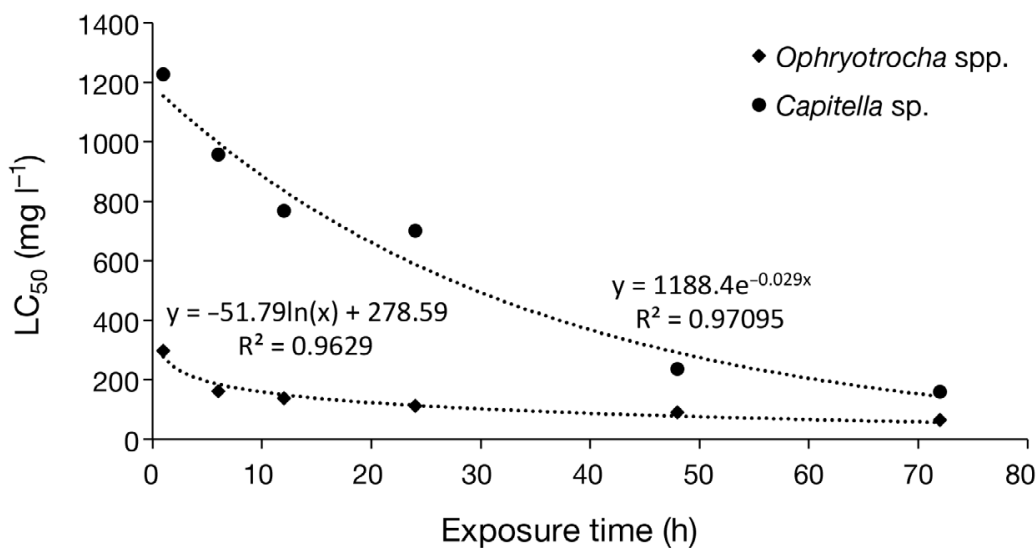

Fig. 2. Lethal concentration $\left(\mathrm{LC}_{50}, \mathrm{mg} \mathrm{l}^{-1}\right)$ of the polychaete species Capitella sp. and Ophryotrocha spp. exposed to hydrogen peroxide at increasing time intervals after exposure. The equations stem from the results of curve estimation analysis of the relationship between $\mathrm{LC}_{50}$ and time

$\mathrm{R}^{2}$ value in an exponential model than in the logarithmic one. The $\mathrm{LC}_{50}$ of Capitella sp. was significantly higher compared to Ophryotrocha spp. at each time interval post exposure ( $t$-test, $\mathrm{p}<0.05)$. The $\mathrm{LC}_{50}$ of Capitella sp. at $1 \mathrm{~h}$ was $1227 \mathrm{mg} \mathrm{l}^{-1}$, and the corresponding value for Ophryotrocha spp. was $296 \mathrm{mg}$ $\mathrm{l}^{-1}$, i.e. 4 times lower. At $72 \mathrm{~h}$ post exposure, the difference was reduced, with a calculated $\mathrm{LC}_{50}$ of 159.3 $\mathrm{mg} \mathrm{l}^{-1}$ for Capitella sp. and $64.3 \mathrm{mg} \mathrm{l}^{-1}$ for Ophryotrocha spp.

Similarly, a significant relation was observed between $\mathrm{LT}_{50}$ and $\mathrm{H}_{2} \mathrm{O}_{2}$ concentrations for both species ( $p<0.05$, Fig. 3). The $\mathrm{LT}_{50}$ for Capitella sp. with 76, 32,33 and $11 \mathrm{~h}$ for the doses 100, 200, 400 and $800 \mathrm{mg} \mathrm{l}^{-1}$, respectively, was significantly longer compared to Ophryotrocha spp., with an $\mathrm{LT}_{50}$ of 24 and $4 \mathrm{~h}$ for doses of 100 and $200 \mathrm{mg} \mathrm{l}^{-1}$, respectively ( $t$-test, $\mathrm{p}<0.05)$. The results thus indicate that more

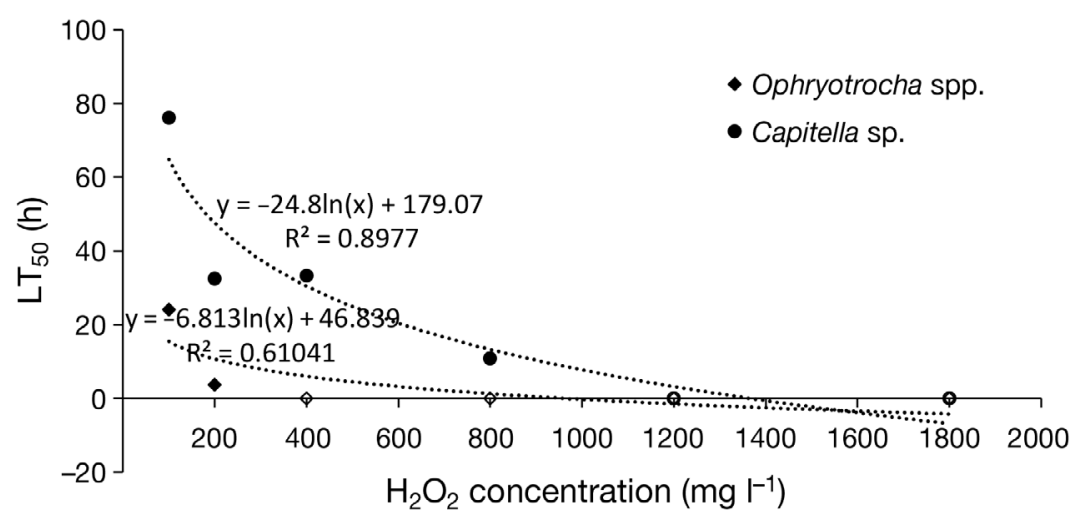

Fig. 3. Lethal time $\left(\mathrm{LT}_{50}, \mathrm{~h}\right)$ of 2 polychaete species (Capitella sp. and Ophryotrocha spp.) exposed to different hydrogen peroxide $\left(\mathrm{H}_{2} \mathrm{O}_{2}\right)$ concentrations. The markers without filling mean the $\mathrm{LT}_{50}$ is less than $1 \mathrm{~h}$. The equations stem from the results of curve estimation analysis of the relationship between $\mathrm{LT}_{50}$ and concentration than $50 \%$ of the Ophryotrocha spp. population would not survive $1 \mathrm{~h}$ exposure to $\mathrm{H}_{2} \mathrm{O}_{2}$ if the concentration exceeded 400 $\mathrm{mg} \mathrm{l}^{-1}$. For Capitella sp., a concentration of $1200 \mathrm{mg} \mathrm{l}^{-1}$ would result in $50 \%$ mortality within $1 \mathrm{~h}$.

\section{DISCUSSION}

Even with an exposure time of only $1 \mathrm{~h}$, both Capitella sp. and Ophryotrocha spp. showed low acute tolerance to the recommended dose of $\mathrm{H}_{2} \mathrm{O}_{2}$ used for delousing. Both species also uncovered limited capacity to recover after exposure to all concentrations tested. An observed effect in both species was change in skin color. The skin of Capitella sp. turned from red to gray during the exposure, and the skin of Ophryotrocha spp. turned from light red to white. This was particularly clear for the high concentrations. Most of the polychaetes that were alive after exposure did not survive the recovery period. Therefore, it seems that the damage from $\mathrm{H}_{2} \mathrm{O}_{2}$ exposure is irreversible in both species and leads to high mortality even at doses that are realistic and ecologically relevant. Further studies should therefore include even lower doses of $\mathrm{H}_{2} \mathrm{O}_{2}$ and be combined with a longer recovery period and studies of sublethal effect parameters. The mortality after $1 \mathrm{~h}$ exposure was considerably lower in Capitella sp. than in Ophryotrocha spp. However, this difference was reduced at the end of the experiment, as both species experienced a substantial mortality in the recovery period. This highlights the importance of including an extended recovery period when studying compounds like $\mathrm{H}_{2} \mathrm{O}_{2}$. Low $\mathrm{H}_{2} \mathrm{O}_{2}$ concentrations $(<2.0$ $\mathrm{mg} \mathrm{l}^{-1}$ ) have previously been shown to cause adverse effects on polychaetes (Abele-Oeschger et al. 1994, Buchner et al. 1996, da Rosa et al. 2008). As Capitella sp. inhabit benthic sediments and may show behavioral avoidance via burrowing, this may affect the exposure to $\mathrm{H}_{2} \mathrm{O}_{2}$ discharged from the farms. However, analytical challenges make it difficult to definitively determine whether discharged $\mathrm{H}_{2} \mathrm{O}_{2}$ might infiltrate the sediment, making burrowing less advantageous. More work should therefore be done to study the effects of $\mathrm{H}_{2} \mathrm{O}_{2}$ on the Capitella sp. when settled in a sediment. For the Ophryotrocha spp. living on the surface of 
the substrate, the situation can indeed be much more critical.

The calculated $\mathrm{LC}_{50}$ of $159.3 \mathrm{mg} \mathrm{l}^{-1}$ for Capitella sp. and $64.3 \mathrm{mg} \mathrm{l}^{-1}$ for Ophryotrocha spp. resembles that for Calanus sp., with an $\mathrm{LC}_{50}$ lower than $5 \%$ of the recommended dose of $1700 \mathrm{mg} \mathrm{l}^{-1}$ (Escobar-Lux 2016). In comparison, Burridge et al. (2014) estimated the $\mathrm{LC}_{50}$ of American lobster larvae (stage 1) to be $1637 \mathrm{mg} \mathrm{l}^{-1}$ after $1 \mathrm{~h}$ exposure and $96 \mathrm{~h}$ recovery time. Corresponding $\mathrm{LC}_{50}$ values for sand shrimp and the chameleon shrimp were 3182 and $937 \mathrm{mg} \mathrm{l}^{-1}$, respectively (Burridge et al. 2014). Using a maximum dose of $1700 \mathrm{mg} \mathrm{l}^{-1}$ of $\mathrm{H}_{2} \mathrm{O}_{2}$ and $1 \mathrm{~h}$ exposure followed by $24 \mathrm{~h}$ recovery, no $\mathrm{LC}_{50}$ could be generated for chameleon shrimp and grass prawns, as the cumulative mortality never exceeded 10\% (Brokke 2015). In comparison, Uc-Peraza \& Delgado-Blas (2015) found that Capitella sp. C was less sensitive to anionic surfactants than the freshwater crustaceans Ceriodaphnia cf. dubia and Daphnia magna and the Nile tilapia Oreochromis niloticus but more sensitive than the Malaysian trumpet snail Melanoides tuberculata. In the studies of Burridge et al. (2014), Brokke (2015), Escobar-Lux (2016) and Fagereng (2016), either the commercial $\mathrm{H}_{2} \mathrm{O}_{2}$ formulation Nemona (Akzo Nobel) or Paramove (49.5\%, Solvay Chemicals International) was used. In comparison, Hansen et al. (2017) used Perhydrol, a 30\% pro-analysis product from Merck, in their study. Whether there may be differences in the toxicity, first between the 2 antisea lice products and second between those products and the pro-analysis product, has to our knowledge not been investigated.

Following treatment, the $\mathrm{H}_{2} \mathrm{O}_{2}$ is released and will disperse horizontally and vertically, if the water column is homogeneous, since a bath solution of $\mathrm{H}_{2} \mathrm{O}_{2}$ is slightly heavier than the surrounding sea water (Refseth et al. 2016). Fagereng (2016), in one of a very limited number of field studies, reported vertical distribution of $\mathrm{H}_{2} \mathrm{O}_{2}$, finding concentrations of 271 to $723 \mathrm{mg} \mathrm{l}^{-1}$ at a depth of $60 \mathrm{~m}$ for nearly $20 \mathrm{~min}$ at one sampling station but also horizontal distribution, where the drug was found in the upper $30 \mathrm{~m}$ and at concentrations up to $69 \mathrm{mg} \mathrm{l}^{-1}$. The discharged $\mathrm{H}_{2} \mathrm{O}_{2}$ from fish farms is therefore likely to be harmful for the polychaetes underneath and in the proximity of the fish farms.

Referring to Sprague (1971), the safe concentration of $\mathrm{H}_{2} \mathrm{O}_{2}$ is assumed to represent $1 \%$ of $\mathrm{LC}_{50}$ at $72 \mathrm{~h}$ for estimation of chronic, sublethal and cumulative $\mathrm{H}_{2} \mathrm{O}_{2}$ toxicity. Using this assumption, the safe concentrations of $\mathrm{H}_{2} \mathrm{O}_{2}$ to Capitella sp. and Ophryotrocha spp. will be 1.59 and $0.64 \mathrm{mg} \mathrm{l}^{-1}$, respectively.
$\mathrm{H}_{2} \mathrm{O}_{2}$ has long been regarded as the most environmentally friendly anti-salmon lice agent. This study demonstrates nonetheless that the potential risk of $\mathrm{H}_{2} \mathrm{O}_{2}$ to aquatic organisms is obvious and serious and therefore requires more attention in research and legislation than previously assumed. It is thereby important to define relevant concentrations of $\mathrm{H}_{2} \mathrm{O}_{2}$ in the environment. Further research should also include non-lethal stress responses and different life stages of the organisms tested.

Acknowledgements. We thank Lerøy Vest AS and Marine Harvest AS for providing access to the farms and help with polychaete collection. Thanks to Anders Mangor-Jensen and Michal Reymer for assistance during the experiment. This research was supported by the Research Council of Norway (263870/H30); Ocean Forest AS (R\&D license project); Environment and Aquaculture Governance (MFA, CHN 2152); Central Public-interest Scientific Institution Basal Research Fund, Chinese Academy of Fishery Science (2018GH15); and Laboratory for Marine Fisheries Science and Food Production Processes, Qingdao National Laboratory for Marine Science and Technology, PR China (2016LMFS-A18).

\section{LITERATURE CITED}

Abele-Oeschger D, Oeschger R, Theede H (1994) Biochemical adaptations of Nereis diversicolor (Polychaeta) to temporarily increased hydrogen peroxide levels in intertidal sandflats. Mar Ecol Prog Ser 106:101-110

Adams MB, Crosbie PBB, Nowak BF (2012) Preliminary success using hydrogen peroxide to treat Atlantic salmon, Salmo salar L., affected with experimentally induced amoebic gill disease (AGD). J Fish Dis 35:839-848

* Bannister RJ, Valdemarsen T, Hansen PK, Holmer M, Ervik A (2014) Changes in benthic sediment conditions under an Atlantic salmon farm at a deep, well-flushed coastal site. Aquacult Environ Interact 5:29-47

Brokke KE (2015) Mortality caused by de-licing agents on the non-target organisms chameleon shrimp (Praunus flexuosus) and grass prawns (Palaemon elegans). MSc dissertation, University of Bergen

Buchner T, Abele-Oeschger D, Theede H (1996) Aspects of antioxidant status in the polychaete Arenicola marina: tissue and subcellular distribution, and reaction to environmental hydrogen peroxide and elevated temperatures. Mar Ecol Prog Ser 143:141-150

*Burridge LE, Lyons MC, Wong DKH, MacKeigan K, VanGeest JL (2014) The acute lethality of three anti-sea lice formulations: AlphaMax ${ }^{\circledR}$, Salmosan ${ }^{\circledR}$, and Interox ${ }^{\circledR}$ Paramove $^{\mathrm{TM}} 50$ to lobster and shrimp. Aquaculture 420-421:180-186

da Rosa CE, Bianchini A, Monserrat JM (2008) Antioxidant responses of Laeonereis acuta (Polychaeta) after exposure to hydrogen peroxide. Braz J Med Biol Res 41: $117-121$

* Dafforn KA, Kelaher BP, Simpson SL, Coleman MA and others (2013) Polychaete richness and abundance enhanced in anthropogenically modified estuaries despite high 
concentrations of toxic contaminants. PLOS ONE 8: e77018

Dean HK (2008) The use of polychaetes (Annelida) as indicator species of marine pollution: a review. Rev Biol Trop 56:11-38

Escobar-Lux R (2016) The effect of an anti sea lice therapeutant, hydrogen peroxide, on mortality, escape response and oxygen consumption on Calanus spp. MSc dissertation, Pierre and Marie Curie University, Paris

Fagereng MB (2016) Use of hydrogen peroxide in aquaculture dilution studies and effects on flower prawns (Pandalus montagui). MSc dissertation, University of Bergen

Grøntvedt RN, Jansen PA, Horsberg TE, Helgesen K, Tarpai A (2015) The surveillance programme for resistance to chemotherapeutants in salmon lice (Lepeophtheirus salmonis). Surveillance programmes for terrestrial and aquatic animals in Norway. Annual report 2014. Norwegian Veterinary Institute, Oslo

Hansen BH, Hallmann A, Altin D, Jenssen BM, Ciesielski TM (2017) Acute hydrogen peroxide $\left(\mathrm{H}_{2} \mathrm{O}_{2}\right)$ exposure does not cause oxidative stress in late-copepodite stage of Calanus finmarchicus. J Toxicol Environ Health A 80:820-829

Institute for Health and Consumer Protection in Finland

Editorial responsibility: Pablo Sánchez Jerez, Alicante, Spain
(2003) Hydrogen peroxide: summary risk assessment report. European Communities, Helsinki

K Kutti T, Hansen PK, Ervik A, Høisæter T, Johannessen P (2007) Effects of organic effluents from a salmon farm on a fjord system. II. Temporal and spatial patterns in infauna community composition. Aquaculture 262:355-366

* Paxton H, Davey A (2010) A new species of Ophryotrocha (Annelida: Dorvilleidae) associated with fish farming at Macquarie Harbour, Tasmania, Australia. Zootaxa 2509: 53-61

Refseth GH, Sæther K, Drivdal M, Nøst OA and others (2016) Miljørisiko ved bruk av hydrogenperoksid. Økologisk vurdering og grenseverdi for effekt. Rapport 8200-1. Akvaplan-niva, Trondheim

Sprague JB (1969) Measurement of pollutant toxicity to fish I. Bioassay methods for acute toxicity. Water Res 3:793-821

* Sprague JB (1971) Measurement of pollutant toxicity to fish-III: sublethal effects and 'safe' concentrations. Water Res 5:245-266

*Uc-Peraza RG, Delgado-Blas VH (2015) Acute toxicity and risk assessment of three commercial detergents using the polychaete Capitella sp. C from Chetumal Bay, Quintana Roo, Mexico. Int Aquat Res 7:251-261

Submitted: March 14, 2018; Accepted: May 21, 2018 Proofs received from author(s): July 23, 2018 